\title{
Evaluation of the quality of different endodontic obturation techniques by digital radiography
}

\author{
Larissa Dantas Fracassi • Eduardo Gomes Ferraz • \\ Sílvio José Albergaria • Elaine Bauer Veeck • \\ Nilza Pereira da Costa • Viviane Almeida Sarmento
}

Received: 12 September 2011 / Accepted: 5 January 2012 /Published online: 19 January 2012

(C) Springer-Verlag 2012

\begin{abstract}
Objectives This study was aimed to evaluate different endodontic obturation techniques (Thermafil, lateral condensation, and Tagger's hybrid technique) regarding the homogeneity of the obturation radiopacity.

Materials and methods Seventy roots of human upper central incisors were filled using the Thermafil system, lateral condensation. and Tagger's hybrid technique. Radiopacity of the filling was evaluated based on mean of grey levels, and its homogeneity was assessed by the coefficient of variation (CV), analyzing the histograms obtained of digitized and digital radiographs.
\end{abstract}

L. D. Fracassi • E. G. Ferraz • S. J. Albergaria • V. A. Sarmento

School of Dentistry, Federal University of Bahia, Brazil,

Av. Araujo Pinho n. 62, Canela,

Salvador, BA CEP 40110-150, Brazil

L. D. Fracassi

e-mail: larissafracassi@hotmail.com

E. G. Ferraz

e-mail: ed_ferraz@yahoo.com.br

S. J. Albergaria

e-mail: silvioalbergaria@gmail.com

E. B. Veeck $\cdot$ N. P. da Costa

School of Dentistry,

Pontifical Catholic University of Rio Grande do Sul,

Av. Ipiranga, 6681 Partenon,

Porto Alegre, RS CEP 90169-900, Brazil

E. B. Veeck

e-mail: ebveeck@terra.com.br

N. P. da Costa

e-mail: nilzet@uol.com.br

V. A. Sarmento $(\bowtie)$

Rua Macaúbas, n. 556, Rio Vermelho,

Salvador, BA, Brazil CEP 41940-250

e-mail: viviane.sarmento@gmail.com
Results The increase in mean grey levels $(p<0.001)$ and reduction in the CV $(p<0.05)$ were higher for Tagger's hybrid technique compared with other methods.

Conclusions Tagger's hybrid technique provided better homogeneity of the obturation radiopacity and better apical sealing compared with lateral condensation technique.

Clinical relevance The results suggest that Tagger's hybrid technique provided the best compaction of the root canal filling material, an important factor for the sealing of obturations and, consequently, for the effectiveness of treatment.

Keywords Radiodensity · Digital radiography · Image quality $\cdot$ Root canal obturation

\section{Introduction}

Lateral condensation is the most widely used obturation technique in endodontics, mainly because of its simple execution and low cost. In view of the limitations of this technique, especially its lack of homogeneity [1], new techniques, using the principle of warm gutta-percha, have been introduced $[2,3]$. Thermomechanical compaction, as proposed by Tagger [3], and the Thermafil carrier system promote the heating of gutta-percha. This permits better adaptation of the material to the internal anatomy of the root canal system [4]. However, possible root canal overfilling due to increased flow of the plasticized material is a disadvantage [5].

Several studies have compared the performance of different obturation techniques in terms of apical sealing capacity measured by dye infiltration [6-8] and homogeneity of the obturation radiopacity [9], but the results are controversial. In addition, there are few studies showing the superiority of some technique [10]. 
One of the tools of digital systems, i.e., the measurement of mean grey levels on an image, has been used over recent years for the quantitative evaluation of the mineral content of teeth and skeletal structure [11, 12], as well as of the radiopacity and homogeneity of dental materials [13]. The advantage of this approach is its objectivity compared to the traditional interpretation of radiographic images, considering the natural limitation of the human eye in distinguishing similar grey tones [14]. In view of this limitation, we evaluated the radiopacity and distribution of endodontic filling material by three different obturation techniques (Thermafil, lateral condensation, and Tagger's hybrid technique). This evaluation was based on the measurement of the mean of the grey levels of pixels on digital images obtained from filled root canals and their apical sealing capacity by dye infiltration.

\section{Materials and methods}

A number of 70 permanent upper central incisors that were previously indicated for extractions were donated by patients at the Discipline of Operative Dentistry, School of Dentistry, Federal University of Bahia (FOUFBA). The study was approved by the Ethics Committee of FOUFBA (process CAAE 0005.0.368.000-07, FR-126218) and all subjects agreed to the donation by signing a free informed consent form.

The teeth were immediately washed with water and soap and then disinfected by immersion in Thymol in $0.1 \%$ water-alcohol solution for $24 \mathrm{~h}$. Next, the teeth were submitted to scaling and planing of the root surfaces with periodontal curettes, and their crowns were removed with a high-speed number 23 carborundum disk at the level of the cementoenamel junction. Root length was measured with a digital caliper (727 Series, Starrett Indústria e Comércio Itu, São Paulo, Brazil), and marks were made on the mesial and buccal surfaces to divide the root into three thirds: cervical, middle, and apical. Perforations were then introduced with a number 1 carbide bur to delimit the thirds. The perforation's depth was the same size of the diameter of the bur $(0.79 \mathrm{~mm})$. These marks could be identified on the radiographic images in both the buccolingual and mesiodistal views.

Next, the teeth were submitted to progressive chemomechanical manual preparation of the root canals, with the working length being established at $1 \mathrm{~mm}$ from the radicular foramen. The canals of all groups were prepared with stainless steel K-Flexofiles (Dentsply Maillerfer). A number 15 file was used to maintain the patency of the foramen. Endo-PTC ${ }^{\circledR}$ plus $1 \%$ sodium hypochlorite were used as auxiliary methods of instrumentation. The teeth were irrigated with $1 \mathrm{ml} 17 \%$ trisodium EDTA for $2 \mathrm{~min}$, followed by irrigation with $5 \mathrm{ml} \mathrm{1 \%}$ sodium hypochlorite, and final washing with $5 \mathrm{ml}$ detergent. All teeth were instrumented and obturated by the same operator.
The roots were randomly divided into the following groups according to the technique used for obturation: Thermafil group, 20 roots obturated using the Thermafil system; lateral condensation group, 20 roots obturated by lateral condensation; Tagger hybrid group, 20 roots obturated using the modified Tagger hybrid technique. The modified Tagger hybrid technique is thermomechanical compaction of the gutta-percha after lateral condensation of the apical part of the master cone. Then, auxiliary cones are introduced again and the thermomechanical compactor is reused, according to Tagger et al. [15].

\section{Conventional and digital radiographs}

The roots were positioned in front of a size 2 radiographic film (sensitivity E) or a phosphor storage plate (PSP) of the DenOptix $^{\circledR}$ digital radiographic system (Gendex, Dentsply, IL, USA), with a resolution of $300 \mathrm{dpi}$. The roots were fixed with adhesive tape behind a soft tissue simulator consisting of an acrylic resin box filled with water (total volume of $4 \mathrm{~mm}^{3}$ ). An aluminum step wedge was attached lateral to the tooth with adhesive tape. This object was used for the subsequent adjustment of the gray level of the radiographs. The X-ray was positioned perpendicular to the tooth and the film or PSP (Fig. 1a, b).

For conventional radiography, a DabiAtlante Spectro 70X generator (Dabi Atlante S.A. Indústrias Médico Odontológicas, Ribeirão Preto, São Paulo, Brazil) operating at $70 \mathrm{kVp}$ and $8 \mathrm{~mA}$ was used. The exposure time was $0.3 \mathrm{~s}$ and the focus film distance was set at $24.5 \mathrm{~cm}$. After exposure, the films were processed using fresh chemical solution (Kodak, New York, USA) in dark chamber under appropriate safety light GBX-2, Kodakusing the temperature-time method. After final washing, the radiographs were dried and stored in plastic folders using a preestablished code.

The radiographs were then digitized with a scanner equipped with a transparency reader (HP PrecisionScan Pro 2.5, ScanJet XPA, Hewlett Packard, Greeley, CO, USA) with a spatial resolution of $600 \mathrm{dpi}$, in the grey scale mode, creating 8-bit images. The position of the radiograph on the active side of the scanner and exposure adjustment were standardized for all acquisitions. All images were saved in BMP format on a CD.

For digital radiography, a TIMEX-70 DRS ${ }^{\circledR}$ X-ray intraoral generator (Gnatus Equipamentos Medico Odontológicos Ltda., Ribeirão Preto, São Paulo, Brazil) operating at $60 \mathrm{kVp}$ and $8 \mathrm{~mA}$, with an exposure time of $0.12 \mathrm{~s}$ and focus film distance of $30 \mathrm{~cm}$, was used. After exposure, the SPS were read and the images were exhibited by the program of the system (Vix Win ${ }^{\mathrm{TM}} 2000^{\circledR}$, Gendex, Dentsply). Next, the digital images were exported, saved on CD in BMP format and properly identified. 
Fig. 1 A, B X-ray tube, specimen, soft tissue simulator, and aluminum step wedge positioned to obtain the radiography

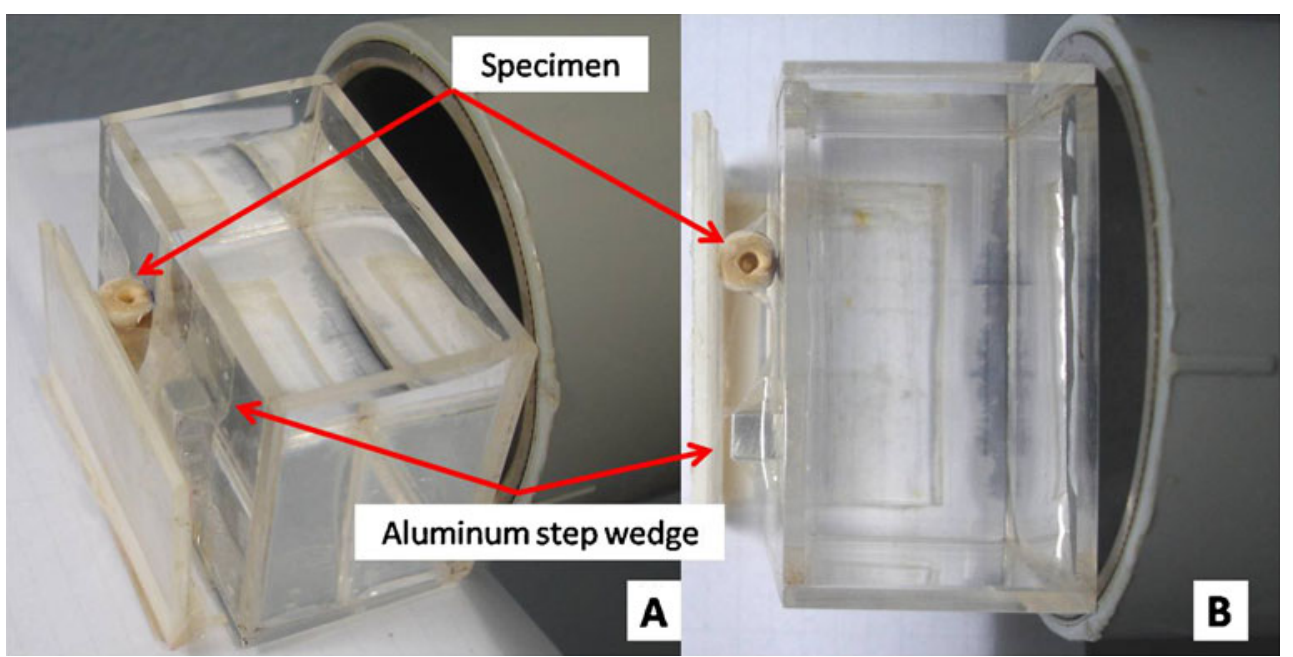

The conventional and digital radiographs were taken in two projections (buccolingual and mesiodistal) before and after root canal obturation. A total of 240 conventional radiographs, corresponding to 240 digitized images, and 240 digital images were obtained.

Before analysis, the brightness of the digitized and digital images was adjusted. Initially, we draw a rectangle area on the third step of the step wedge of the first scanned radiography, and we measured its gray value (obtained from the histogram). This value was considering the reference to make the adjustment. After that, the gray value of the third step of the second radiograph was also measured and compared to the value of the first radiograph. Difference between the radiographs was calculated and reduced or increased to all pixels of the second radiography. This procedure was repeated in all radiographs. The digital and digitized images were then opened with the ImageTool ${ }^{\circledR}$ program (University of Texas Health Science Center, San Antonio, TX, USA). The histogram tool was used to measure the mean of the grey levels and the standard deviation of grey levels separately in the cervical, middle and apical portions of the root canal, before and after obturation. We measured the value of gray of a rectangle whose width was the same size of the root canal. The dentin was not included in this rectangle. The values obtained were used to calculate the coefficient of variation (CV) of grey levels in the area $(\mathrm{CV}=$ standard deviation/mean), with a low value indicating homogeneity of the root canal filling. Changes in the appearance of the image other than the previously performed brightness correction were not possible for this analysis, because of our research protocol.

This analysis was performed by the same observer, expert in Radiology, twice, at an interval of one week between assessments. The mean of the two values obtained for mean of the grey level and $\mathrm{CV}$ was calculated for each specimen and recorded on a specific chart for subsequent analysis.

\section{Evaluation of dye infiltration}

For the evaluation of apical seal, ten additional teeth were submitted to chemomechanical root canal preparation and served as positive or negative controls of dye infiltration.

On the outer surfaces of the obturated roots (Thermafil, lateral condensation, and Tagger's hybrid technique) were applied one layer of adhesive glue and another layer of nail polish, except for an area of approximately $2 \mathrm{~mm}$ surrounding the radicular foramen. In evaluating dye infiltration, five of the ten nonobturated control roots, the adhesive glue and another layer of nail polish were applied in all root surface, including the entire apical portion (negative control $/ n=5$ ), and on other five roots, an area of $2 \mathrm{~mm}$ around the apical foramen was left without adhesive glue (positive control $/ n=5$ ). After, the roots were immersed in $2 \%$ methylene blue dye for 7 days in an oven at $37^{\circ} \mathrm{C}$, followed by washing with water for $24 \mathrm{~h}$. The roots were cut longitudinally until close to the filling material with a carborundum disk and then cleaved with a chisel. The extent of dye infiltration inside the root canal was evaluated with a stereomicroscopic magnifying glass (Stemi 2000, Carl Zeiss, Germany) by two expert in Endodontics, who determined the extent (in $\mathrm{mm}$ ) of dye penetration using a millimeter ruler. The highest degree of infiltration observed for the two sections of each specimen was chosen for analysis. Since the working length was not a controlled variable, the degree of infiltration was evaluated proportionally to the working length. These data were recorded on a specific chart.

\section{Data analysis}

The Student's $t$ test was used to compare mean of the grey levels and $\mathrm{CV}$ before and after obturation. Percentage of the gain in grey levels mean and percentage reduction in $\mathrm{CV}$ 
were compared by analysis of variance (ANOVA) followed by the Tukey-Kramer or Dunnet post hoc test. Since the data showed no normal distribution, the degree of dye penetration was compared between groups by the KruskalWallis test followed by Dunn's post hoc test. Interexaminer agreement was evaluated using Spearman's correlation coefficient.

Mean grey levels were compared before and after obturation by the three techniques for the three thirds of the root, the two projections and the two radiographic imaging modalities (digitized and digital radiographs).

\section{Results}

A significant increase in mean of the grey levels after obturation was observed for all analyses (Student's $t$ test, $p<0.001$; Tables 1 and 2). A significant difference in the CV before and after obturation was observed for digitized and digital images (Student's $t$ test, $p<0.05$ ), except for the lateral condensation group in the cervical third when analyzing digital images obtained in the buccolingual projection (Tables 3 and 4). Analysis of dye infiltration showed that Tagger's hybrid technique was superior to lateral condensation and did not differ significantly from the Thermafil technique (Table 5). Analysis of interobserver agreement showed a strong significant correlation (0.987).

\section{Discussion}

Mean of the gray level refers to the average of the radiodensity value of the pixels of a selected area. In this case, we selected a

Table 1 Mean percent gain (MPG) of grey levels in the cervical (C), middle (M) and apical (A) third of root canals obturated by the Thermafil, lateral condensation and Tagger hybrid techniques on digitized images obtained in the mesiodistal (MD) and buccolingual (BL) view

\begin{tabular}{|c|c|c|c|c|}
\hline & \multicolumn{3}{|l|}{ MPG } & \multirow[t]{2}{*}{$p$ Value } \\
\hline & Thermafil & $\begin{array}{l}\text { Lateral } \\
\text { condensation }\end{array}$ & $\begin{array}{l}\text { Tagger's } \\
\text { hybrid }\end{array}$ & \\
\hline C MD & $24.49 \% \%^{\mathrm{a}, \mathrm{b}}$ & $28.47 \%^{\mathrm{a}}$ & $28.89 \%^{\mathrm{b}}$ & $0.0107^{*}$ \\
\hline $\mathrm{C} B \mathrm{BL}$ & $23.74 \%$ & $25.91 \%$ & $25.01 \%$ & 0.3291 \\
\hline M MD & $23.27 \%^{\mathrm{c}, \mathrm{d}}$ & $27.34 \%^{\mathrm{c}}$ & $30.02 \%{ }^{\mathrm{d}}$ & $<0.0001^{*}$ \\
\hline M BL & $20.97 \%$ & $23.04 \%$ & $24.14 \%$ & 0.1081 \\
\hline A MD & $24.74 \%^{\mathrm{e}, \mathrm{f}}$ & $30.01 \%{ }^{\mathrm{e}}$ & $32.05 \%{ }^{\mathrm{f}}$ & $0.0002 *$ \\
\hline A BL & $21.43 \%^{\mathrm{g}}$ & $24.59 \%$ & $26.72 \% \mathrm{o}^{\mathrm{g}}$ & $0.0147^{*}$ \\
\hline
\end{tabular}

*Statistically significant difference (ANOVA, $p<0.05$ )

${ }^{\mathrm{a}, \mathrm{b}, \mathrm{c}, \mathrm{g}}$ Statistically significant difference (Tukey-Kramer test, $p<0.05$ ).

${ }^{\mathrm{d}, \mathrm{e}, \mathrm{f}}$ Statistically significant difference (Tukey-Kramer test, $p<0.001$ ).
Table 2 Mean percent gain (MPG) of grey levels in the cervical (C), middle (M) and apical (A) third of root canals obturated by the Thermafil, lateral condensation and Tagger hybrid techniques on digital images obtained in the mesiodistal (MD) and buccolingual (BL) view

\begin{tabular}{|c|c|c|c|c|}
\hline & \multicolumn{3}{|l|}{ MPG } & \multirow[t]{2}{*}{$p$ Value } \\
\hline & Thermafil & $\begin{array}{l}\text { Lateral } \\
\text { condensation }\end{array}$ & $\begin{array}{l}\text { Tagger's } \\
\text { hybrid }\end{array}$ & \\
\hline C MD & $43.67 \%^{\mathrm{a}}$ & $45.46 \%$ & $49.96 \%{ }^{\mathrm{a}}$ & $0.048^{*}$ \\
\hline C BL & $39.56 \%^{\mathrm{b}}$ & $39.53 \%^{\mathrm{c}}$ & $45.42 \%^{\mathrm{b}, \mathrm{c}}$ & $0.0274 *$ \\
\hline M MD & $44.04 \%{ }^{\mathrm{d}}$ & $47.54 \%{ }^{\mathrm{e}}$ & $55.51 \%{ }^{\mathrm{d}, \mathrm{e}}$ & $0.0019^{*}$ \\
\hline M BL & $37.43 \%{ }^{\mathrm{f}}$ & $38.12 \%^{\mathrm{g}}$ & $46.25 \% \%^{\mathrm{f}, \mathrm{g}}$ & $0.0025^{*}$ \\
\hline A MD & $60.97 \%$ & $65.63 \%$ & $73.98 \%$ & 0.0597 \\
\hline A BL & $48.27 \%{ }^{\mathrm{h}}$ & $52.13 \%$ & $61.87 \%{ }^{\mathrm{h}}$ & $0.0165^{*}$ \\
\hline
\end{tabular}

* Statistically significant difference (ANOVA, $p<0.05$ ).

${ }^{\mathrm{a}, \mathrm{e}, \mathrm{g}, \mathrm{h}}$ Statistically significant difference (Tukey-Kramer test, $p<0.05$ ).

${ }^{\mathrm{b}, \mathrm{c}}$ Statistically significant difference (Dunnett test, $p<0.05$ ).

${ }^{\mathrm{d}, \mathrm{f}}$ Statistically significant difference (Tukey-Kramer test, $p<0.01$ ).

rectangular area within the root canal and we measure the mean of pixels radiodensity. This number ranges from 0 (black pixels) to 255 (white pixels) on an 8-bit grey scale image. Higher values indicate a radiopaque area. Lower values indicate a radiolucent area. Some studies in the literature use this resource [11, 12, 16-18]. In the present study, this value indicated the degree of radiolucency of the empty root canal before obturation and the radiopacity of the filling material after obturation. Insertion of the radiopaque filling material is known to increase the mean grey level. This is observed for any obturation technique, irrespective of its efficiency.

Table 3 Mean percent reduction (MPR) of the CV in the cervical (C), middle (M) and apical (A) third of root canals obturated by the Thermafil, lateral condensation and Tagger hybrid techniques on digitized images obtained in the mesiodistal (MD) and buccolingual (BL) view

\begin{tabular}{|c|c|c|c|c|}
\hline & \multicolumn{3}{|l|}{ MPR } & \multirow[t]{2}{*}{$p$ Value } \\
\hline & Thermafil & $\begin{array}{l}\text { Lateral } \\
\text { condensation }\end{array}$ & $\begin{array}{l}\text { Tagger's } \\
\text { hybrid }\end{array}$ & \\
\hline $\mathrm{C} \mathrm{MD}$ & $13.65 \%$ & $6.81 \%^{\mathrm{a}}$ & $21.57 \%^{\mathrm{a}}$ & $0.0013^{*}$ \\
\hline $\mathrm{C} B L$ & $10.01 \%$ & $13.14 \%$ & $17.33 \%$ & 0.3527 \\
\hline M MD & $12.73 \%$ & $12.52 \%$ & $18.52 \%$ & 0.2733 \\
\hline M BL & $6.30 \%{ }^{\mathrm{b}}$ & $13.56 \%$ & $17.63 \%^{\mathrm{b}}$ & $0.0284 *$ \\
\hline A MD & $16.46 \%$ & $10.92 \%$ & $15.32 \%$ & 0.3020 \\
\hline A BL & $10.21 \%$ & $15.18 \%$ & $16.85 \%$ & 0.3904 \\
\hline
\end{tabular}

*Statistically significant difference (ANOVA, $p<0.05$ ).

${ }^{a}$ Statistically significant difference (Tukey-Kramer test, $p<0.001$ ).

${ }^{\mathrm{b}}$ Statistically significant difference (Tukey-Kramer test, $p<0.05$ ). 
Table 4 Mean percent reduction (MPR) of the CV in the cervical (C), middle (M) and apical (A) third of root canals obturated by the Thermafil, lateral condensation and Tagger hybrid techniques on digital images obtained in the mesiodistal (MD) and buccolingual (BL) view

\begin{tabular}{lcccc}
\hline & \multicolumn{3}{l}{ MPR } & $p$ Value \\
\cline { 2 - 4 } & Thermafil & $\begin{array}{l}\text { Lateral } \\
\text { condensation }\end{array}$ & $\begin{array}{l}\text { Tagger's } \\
\text { hybrid }\end{array}$ & \\
\hline C MD & $11.78 \%$ & $9.16 \%$ & $19.17 \%$ & 0.0575 \\
C BL & $9.15 \%$ & $3.00 \%^{\mathrm{a}}$ & $15.01 \%^{\mathrm{a}}$ & $0.0045^{*}$ \\
M MD & $24.89 \%$ & $29.75 \%$ & $32.28 \%$ & 0.2377 \\
M BL & $20.85 \%$ & $20.47 \%^{\mathrm{c}}$ & $30.04 \%{ }^{\mathrm{b}, \mathrm{c}}$ & $0.0200^{*}$ \\
A MD & $38.47 \%$ & $38.51 \%$ & $40.37 \%$ & 0.8982 \\
A BL & $29.57 \%$ & $37.11 \%$ & $39.52 \%$ & 0.1513 \\
\hline
\end{tabular}

*Statistically significant difference (ANOVA, $p<0.05$ ).

${ }^{a}$ Statistically significant difference (Tukey-Kramer test, $p<0.01$ ).

${ }^{\mathrm{b}, \mathrm{c}}$ Statistically significant difference (Tukey-Kramer test, $p<0.05$ ).

Since human permanent teeth were used, even taking care to select the same group of teeth, it was not possible to obtain a homogenous sample in terms of mean grey levels before obturation (which would correspond to the radiolucency of the root canal determined by its volume) and thus to eliminate this variable. In view of this limitation and to permit a more reliable comparison of the increase in mean of the grey levels after obturation, the percentage increase in mean values after obturation was used for analysis (Table 1, digitized image; Table 2, digital image). Thus, the question was which technique would provide a larger increase in the radiopacity of the filling material, i.e., permit more effective root canal filling.

In general, the highest differences were observed between Tagger's hybrid technique and the Thermafil system. This finding might be related to a lower radiopacity of the alpha phase gutta-percha of the Thermafil obturator due to its lower molecular weight as described in the instructions of the Thermafil plus endodontic obturator [19] or even to the presence of the plastic carrier (which may present a lower resistance to the passage of X-rays

Table 5 Median percent dye infiltration in root canals obturated by the Thermafil, lateral condensation and Tagger hybrid techniques

\begin{tabular}{lllll}
\hline Examiner & Thermafil & $\begin{array}{l}\text { Lateral } \\
\text { condensation }\end{array}$ & $\begin{array}{l}\text { Tagger's } \\
\text { hybrid }\end{array}$ & $p$ Value \\
\hline 1 & $63.65 \%^{\mathrm{a}}$ & $88.75 \% \%^{\mathrm{a}, \mathrm{b}}$ & $72.9 \%^{\mathrm{b}}$ & $0.0040^{*}$ \\
2 & $62.30 \%^{\mathrm{c}}$ & $87.50 \%{ }^{\mathrm{c}, \mathrm{d}}$ & $70.4 \%^{\mathrm{d}}$ & $0.0039^{*}$
\end{tabular}

*Statistically significant difference (Kruskal-Wallis test, $p<0.05$ )

a,b,c,d Statistically significant difference (Dunn's multiple comparisons test, $p<0.05$ ) than gutta-percha), rather than to the lower efficiency of this technique. The results of this study demonstrated a more effective condensation of gutta-percha caused by McSpadden thermal compaction on digitized and digital images, with a tendency toward a higher filling percentage, although not always statistically significant, in the Tagger hybrid group.

In the case of lateral condensation, excess gutta-percha in the coronary portion is removed with a hot instrument. In Tagger's hybrid technique, this excess material is partially removed and is added to the material inside the root canal by the action of the compactor. This fact might explain the increase of mean grey levels in the Tagger hybrid group when compared to lateral condensation.

An increase in mean grey levels after root canal obturation has also been reported by Sarmento et al. [18]. However, these authors only evaluated the lateral condensation technique compared to obturation with endodontic cement and secondary cones. A higher percentage increase in mean of the grey levels was obtained with the lateral condensation technique when compared to the other two groups.

The CV of mean grey levels corresponds to the dispersion of grey values around the mean and a low coefficient indicates the homogeneity of the root canal filling. For CV, percentage loss was compared between the different groups since, according to Sarmento et al. [18] the insertion of a filling material into the root canal by techniques that permit compaction of the filler results in greater homogeneity, i.e., a lower $\mathrm{CV}$ compared to the root canal space before obturation.

In general, the percentage reduction in $\mathrm{CV}$ was higher for Tagger's hybrid technique compared to the two other obturation techniques. This finding might be explained by the action of the thermal compactor that plasticizes the gutta-percha, condensing the primary and secondary cones and thus forming a single, more homogenous mass. According to Artaza [20], the hybrid technique is characterized radiographically by the formation of a dense and homogenous mass and microscopically by the incorporation of the cement into the mass of gutta-percha. In the lateral condensation group, microscopically, only the apical third was found to be homogenous, and the accessory cones were separated in the middle and coronary thirds, and radiography revealed the presence of voids in the middle third. These results suggest that Tagger's hybrid technique provided the best compaction of the root canal filling material, an important factor for the sealing of obturations and, consequently, for the effectiveness of treatment.

The results of the present study demonstrated lower apical infiltration in the Thermafil group, although the difference was only statistically significant when compared to the lateral condensation group. Tagger's hybrid technique 
also promoted significantly better apical sealing when compared to the lateral condensation technique (Table 5). Several studies have investigated the apical sealing capacity of endodontic obturation techniques. Some studies showed higher apical infiltration for the lateral condensation technique compared to the hybrid technique and better apical sealing of lateral condensation compared to Thermafil technique [21]. Other studies demonstrated the superiority of lateral condensation [22], whereas some investigators did not observe a significant difference between lateral condensation and thermoplasticizing technique [23].

In the present study, extrusion of the sealer was observed in all specimens after obturation. Patency of the foramen was maintained with a number 15 file to prevent the accumulation of smear layer in the root apex. Gilhooly et al. [24] also observed a high frequency of extrusion of the root canal filling material (about one third of samples). The authors attributed the rate of extrusion of sealer or gutta-percha to the patency and emphasized that some factors may impair this extrusion like the periodontal ligament and tissue fluids at the periapical area. These factors are not present in vitro studies. Pereira et al. [25] agreed that certain factors present in a clinical situation act as natural barriers to extrusion.

Extrusion of gutta-percha was only observed in root canals filled with Thermafil $(n=11,55 \%)$. High rates of extrusion have also been reported by other investigators $[5,26]$. As in the present study, Carvalho et al. [27] also used upper central incisors, which present wide and straight canals and are therefore more susceptible to apical extrusion. According to Berger [28], Thermafil is indicated for curved and tight canals. Thus, the characteristic of easy extrusion of Thermafil can be controlled in tight canals in the apical third. Some studies have reported a tendency toward extrusion of the filling material for Tagger's hybrid technique $[29,30]$. In the present study, no extrusion of gutta-percha was observed in the Tagger hybrid group. Pereira et al. [25] also found no extrusion of the filling material in any of the specimens studied. However, the high incidence of extrusion of gutta-percha observed in the present investigation for the Thermafil group might have contributed to the better apical sealing provided by this technique.

The present study demonstrated the superiority of Tagger's hybrid technique in terms of homogeneity of radiopacity of root canal fillings. This technique showed better scores for homogeneity of the obturation radiopacity (an increase in mean of the grey levels) and better homogeneity (a reduction in the CV). Analysis of dye infiltration showed that Tagger's hybrid technique was superior to lateral condensation and did not differ significantly from the Thermafil technique, in agreement with the results of the radiographic analysis.

\section{Conclusions}

Tagger's hybrid technique presented a higher percent gain of mean grey levels after root canal filling, which was significant in most assessments. A greater percent reduction in the $\mathrm{CV}$ after obturation was observed for Tagger's hybrid technique, but the difference was not significant in most assessments. Tagger's hybrid technique provided better homogeneity of the obturation radiopacity and better apical sealing compared to the lateral condensation technique. The Thermafil technique showed lower results in relation to the mean grey levels. With regard to dye infiltration Thermafil technique was the better performance, followed by Tagger's hybrid technique and Lateral condensation, in this order.

Acknowledgments The authors thank CAPES (Ministery of Education, Brazil) for the scholarship granted for the first author.

Conflicts of Interest None

\section{References}

1. Schilder H (1967) Filling root canals in three dimensions. Dent Clin North Am 11:723-744

2. Johnson WB (1978) A new gutta-percha techinique. J Endod 4:184-188

3. Tagger M (1984) Use of thermo-mechanical compactors as an adjunct to lateral condensation. Quintessence Int 15:27-30

4. Weller RN, Kimbrough WF, Anderson RW (1997) A comparison of thermoplastic obturation techiniques: adaptation to the canal walls. J Endod 23:703-706

5. Jarrett IS, Marx D, Covey D, Karmazin M, Lavin M, Gound T (2004) Percentage of canals filled in apical cross sections - an in vitro study of seven obturation techniques. Int Endod $\mathrm{J}$ 37:392-398

6. Inan U, Aydemir H, Tasdemir T (2007) Leakage evaluation of three different root canal obturation techniques using electrochemical evaluation and dye penetration evaluation methods. Aust Endod J $33: 18-22$

7. Schäfer E, Olthoff G (2002) Effect of three different sealers on the sealing ability of both thermafil obturators and cold laterally compacted gutta-percha. J Endod 28:638-642

8. Venturi M, Breschi L (2004) Evaluation of apical filling after warm vertical gutta-percha compaction using different procedures. J Endod 46:436-440

9. Dummer PMH, Lyle L, Rawle J, Kennedy JK (1994) A laboratory study of root fillings in teeth obturated by lateral condensation of gutta-percha or Thermafil obturators. Int Endod J 27:32-38

10. Whitworth J (2005) Methods of filling root canals: principles and practices. Endod Topics 12:2-24

11. Cunha SS, Sarmento VA, Ramalho LMP, Almeida D, Veeck EB, Costa NP, Mattos A, Marques AM, Gerbi M, Freitas AC (2007) Effect of laser therapy on bone tissue submitted to radiotherapy: experimental study in rats. Photomed Laser Surg 25:197-204

12. Azoubel MCF, Sarmento VA, Lima VLC, Azoubel E, Bittencourt S, Cunha FQ, Ribeiro RA, Brito GAC (2008) Adjunctive benefits of systemic etoricoxib in non-surgical treatment of aggressive periodontitis short-term evaluation. J Periodontol 79:1719-1725 
13. Fonseca RB, Branco CA, Soares PV, Correr-Sobrinho L, Haiter-Neto F, Fernandes-Neto AJ, Soares CJ (2006) Radiodensity of base, liner and luting dental materials. Clin Oral Invest 10:114-118

14. Ohki M, Okano T, Nakamura T (1994) Factors determining the diagnostic accuracy of digitized conventional intraoral radiographs. Dentomaxillofacial Radiol 23:77-82

15. Tagger M, Santa Cecília M, Moraes IG (1994) Técnica híbrida de Tagger: Modificações do método original. RGO (Porto Alegre) 42:207-208

16. Dutra GMC, Wienandts P, Costa NP, Araujo FB (2007) Avaliação da densidade óptica da superfície oclusal através de radiografias digitalizadas e sua relação com a presença de lesões de cárie em molares decíduos. Rev Odonto Ciênc 22:222-227

17. Tanaka JLO, Medici Filho E, Salgado JAP, Salgado MAC, Moraes LC, Moraes MEL, Castilho JCM (2008) Comparative analysis of human and bovine teeth: radiographic density. Braz Oral Res 22:346-351

18. Sarmento VA, Ramalho LMP, Löf AS, Spohr AM, Costa NP (1998) Avaliação da qualidade de obturação endodôntica através da digitalização direta de imagens. Rev Odonto Ciênc 13:139-155

19. Dentsply Tulsa Dental (2002) Instruction Manual for use with Thermafil ${ }^{\circledR}$ Plus Endodontic Obturators. http://www.store.tulsadental. com/lit/pdfs/TUD-2065_therfil+instr.pdf. Accessed 4 April 2008

20. Artaza LP (1999) Evaluación del sellado apical obtenido por tres tecnicas de obturación endodóntica con Gutapercha termoplastizada. Rev Asoc Odontol Argent 87:54-59

21. Tagger M, Tamse A, Katz A, Korzen BH (1984) Evaluation of the apical seal produced by a hybrid root canal filling method, combining lateral condensation and thermatic compaction. J Endod 10:299-303
22. Haikel Y, Freymann M, Fanti V, Claisse A, Poumier F, Watson M (2000) Apical microleakage of radiolabeled lysosyme over time in three techniques of root canal obturation. J Endod 26:148-152

23. Abarca AM, Bustos A, Navia M (2001) A comparison of apical sealing and extrusion between Thermafil and lateral condensation techniques. J Endod 27:670-672

24. Gilhooly RMP, Hayes SJ, Bryant ST, Dummer PMH (2001) Comparison of lateral condensation and thermomechanically compacted warm $\alpha$-phase gutta-percha with a single cone for obturating curved root canals. Oral Surg Oral Med Oral Pathol Oral Radiol Endod 91:89-94

25. Pereira AJA, Fidel RAS, Fidel SR, Souza MI (1999) Avaliação radiográfica do deslocamento apical da obturação de canais radiculares promovido pelo compactador de McSpadden na técnica híbrida de Tagger. Rev Bras Odontol 56:264-267

26. Gutmann JL, Saunders WP, Saunders EM, Nguyen L (1993) An assessment of the plastic Thermafil obturation technique: Part 1. Radiographic evaluation of adaptation and placement. Int Endod J 26:173-178

27. Carvalho E, Andrade Júnior J, Malvar MF, Albergaria S (2006) Avaliação do selamento apical em dentes obturados pela técnica da condensação lateral híbrida, de Tagger e Thermafil. Rev Ciênc Med Biol 5:239-244

28. Berger CR (1995) Thermafil: avaliação clínica. Rev Odontol UNICID 7:19-26

29. Cruz RM, Barbosa SV (1994) Análise das técnicas Termomecânicas de obturação dos canais: McSpadden, Híbrida e mista. ROBRAC 4:23-28

30. Zmener O, Perruchino R, Zacarias M (2002) Análise da qualidade da obturação endodôntica obtida por meio de duas técnicas de guta-percha termoplastificada. J Endod Pract 1:30-34 